\title{
Socio-demographic and economic indicators in gender structure in the middle Taurus mountainous villages of Turkey
}

\author{
Müge Kantar Davran ${ }^{1 *}$ (D) Burak Öztornaci ${ }^{1}$ (D) Burhan Özalp ${ }^{1}$ \\ ${ }^{1}$ University of Çukurova, Faculty of Agriculture, Department of Agricultural Economics, 01330, Adana-Turkey. E-mail: mkantar@cu.edu.tr. \\ ${ }^{*}$ Corresponding author. \\ ABSTRACT: Socio-demographic and economic indicators are very important clues to scientists and institutions to direct development \\ programs for the empowerment of rural women. The goal of this study is to determine the status of rural women living in the Taurus mountainous \\ villages of Turkey according to socio-demographic and economic indicators as related to gender structure. In this research area, there is not \\ enough official data related to socio-demographic and economic indicators about mountainous rural women, like in most developing countries. \\ For this study, the authors collected data from 146 women and 133 men using questionnaires and face-to-face interviews. In this research area, \\ we found that women occupy positions of low power compared to men when taking socio-demographic and economic indicators into account. \\ Women tend to define themselves as housewives instead of farmers, and their tendency to migrate to cities were higher than men's. \\ Key words: woman issue, rural area, rural development, statistical indicators.
}

Indicadores sócio-demográficos e econômicos em termos de estrutura de gênero nas aldeias Taurus Mountainous Villages da Turquia

RESUMO: Os indicadores sócio-demográficos e econômicos são muito importantes, não só para o cientista, para o empoderamento das mulheres rurais, mas também para que as instituições direcionem os programas de desenvolvimento relacionados com as mulheres rurais. $O$ objetivo deste estudo foi determinar o status de mulheres rurais com indicadores sócio-demográficos e econômicos em termos de estrutura de gênero que vivem em aldeias Taurus Mountainous Villages da Turquia. Na área de pesquisa, dados oficiais relacionados a indicadores sociodemográficos e econômicos sobre estas mulheres não são suficientes, como na maioria dos países em desenvolvimento. Os dados foram coletados de 146 mulheres e 133 homens, por meio de questionário e entrevista presencial dos autores. Na área de pesquisa, as mulheres estão atrás de indicadores sócio-demográficos e econômicos relacionados aos homens e têm posição secundária de acordo com os dados obtidos. As mulheres se definem como uma dona de casa em vez de agricultoras e a tendência de migração das mulheres para as cidades são maiores do que a dos homens.

Palavras-chave: Status das mulheres rurais, áreas montanhosas, gênero, Turquia.

\section{INTRODUCTION}

Understanding socio-demographic and economic indicators like education, occupation, age at first marriage, and marriage decisions is very important to understand women's status and their needs at home and in society. These indicators impact the main guidelines for implementing successful development projects related to women and their empowerment (BENERIA et al., 2015; CANTALINI, 2017). These indicators change from country to country and from region to region within each country (ZAINIDDINOV, 2016; BRYM \& ANDERSEN, 2016; KOCOURKOVA, 2016). It is obvious that women have lower positions than men based on all socio-demographic/economic indicators studied; all of them have an impact on women's status, especially education, marriage, and occupation. Nevertheless, in most countries, women are typically not counted in socio-demographic or economic indicator statistics. When educational and occupational data for women are analyzed, it is less positive than men's; unlike men, women generally drop out of school to help with chores or farm work (BATANA, 2013). In agricultural occupations, women begin working at earlier ages and in younger age groups than men. Male participation in agricultural occupations is lower in rural areas because boys continue with 
their high school education (WORLD BANK, 1993). Education is the most important indicator for empowerment of women both at home and in society because it creates a bridge for women to access health services, land, credit facilities, etc. (DHANARAJ \& MAHAMBARE, 2019). MORRISON et al. (2007) explained that increasing the number of educated women is a key factor for empowering women. While many worldwide studies have documented the importance of women's education for its impact on child schooling and nutrition, education is also important to women. Basic education provides a foundation for developing the flexible skills needed to participate in knowledge-intensive economic activity (KHURSHID, 2016).

Education is a driving force for any country's development. However, in Turkey, school enrollment rates for girls are lower than for boys. There are several obstacles for girls' schooling (TOR \& AĞLI, 2016). These obstacles can be classified as religious, economic, traditional, and rural (KARAMAN, 1994). In particular, economic obstacles directly affect women: under current economic conditions, families generally prioritize boys; only later girls have the opportunity to benefit from schooling (KHURSHID, 2016).

Women cannot easily access education activities due to patriarchy, economic insufficiency, high illiteracy rates, etc. KANTAR's study (2001), which was carried out in the mountainous villages of the Adana and İçel provinces, reported that the illiteracy rate for women was $62.5 \%$.

Rural, and especially mountain, women are generally not considered key contributors to development projects, and they have a disadvantageous position compared to both men and urban women. Common challenges for mountain women included their limited access to social services, credit facilities, and agricultural extension; literacy levels are low and they have minimal or no control over resources (ICIMOD, 1997). OGBUAGU (1996) explained that, by nature of their location and associated differential development, rural women suffer from various disabilities compared to urban residents. However, social restrictions and poorer demographic experiences impose greater constraints on rural women than on urban women. According to FAO's 2004 study, National Sectoral Report on Women, Agriculture and Development, which was conducted in Iran, Benin, Cameroon, Honduras, Lebanon, Burkina Faso, Congo, El Salvador, Mauritania, and Egypt, women play an active part in agriculture as farmers but traditionally have little decision-making power. Moreover, data on women are traditionally excluded from statistics and women's work is not calculated in the country's GDP. As a result, there is lack of gender disaggregated data. Also, it is difficult for women to reach extension services. In Iran, since agricultural income is often insufficient for subsistence, rural women's nonagricultural activities such as carpet weaving and other crafts are important for household survival. In Burkina Faso, only $8 \%$ of women were literate in 1992 , compared to $23.5 \%$ of men. In Mauritania, illiteracy and lack of access to formal education are important negative factors for children, especially for girls. In Egypt, $38 \%$ of men and $62 \%$ of women are illiterate. These figures are not different today. Of the world's 774 million illiterate adults, two-thirds are women, and this share of illiterate women has not changed for the past 20 years. Among the world's 123 million illiterate youth, 76 million are female. These gender disparities persist, with little change over time (UNESCO, 2014).

In addition to education and women's exclusion from development projects, other important indicators are early marriage and high number of children born per woman in rural areas (DOSS, 2013). Although, first marriage age is increasing, it is still low and falls between 17 and 20 for girls in developing countries. Early marriage age is one of the main obstacles to women's access to education, health services, normal work load, qualified jobs, etc. OGBUAGO (1996) stated that early marriage and early childbearing age are the norm in traditional societies. Currently, for girls in Asia, Africa, and Latin America, 18\%, 16\% and 8\% marry before age 15, respectively (OGBUAO, 1996). Generally, women marry earlier than men (18 and 23 in Nigeria, for example) and rural women marry even earlier than their urban counterparts (GOODY, 1989). MAERTENS (2013) stated that the socially acceptable marriage age in India is, on average, 18.3 years for girls and 22.7 years for boys. JENSON and THORNTON's study (2003), which focused primarily on Benin, Colombia, India, and Turkey, reported strong correlations between woman's age at marriage and the level of education she achieves, as well as the age at which she gives birth to her first child and her husband's age.

Gender-biased marriage age for girls often means limited schooling, entry into lowpaying jobs, and early childbearing with its associated reproductive health problems. Constant childbearing coupled with hard work and low or no education in traditional settings often have adverse 
effects on both the mother's and children's health and contribute significantly to high morbidity and mortality rates (BOSERUP, 1989). Societies, which are often patrilocal, reinforce gender inequality and value high fertility rates (GOODY, 1989; ANONYMOUS, 2017).

Aside from these indicators, another important point is the absence of sufficient sociodemographic, economic, and demographic data about rural and especially mountain women in developing countries. Unfortunately, scarcity of rural-gender disaggregated data restricts the extent of analysis (OGBUAGO, 1996). There is not enough official data related to socio-demographic and economic indicators about mountainous rural women in our research area, like in most developing countries. As a general observation, results obtained from the gender studies perspective generally do not favor women. However, it is very important to have information about the quality and quantity of women's issues in order to begin to solve women's problems and create a consistent data source. Obtaining this kind of data will contribute to rural development studies, rural experts, rural women and improved gender studies. Otherwise, studies will continue to conclude that women have secondary positions and disadvantaged status in society.

The goal of this article was to contribute to the literature related to rural development in mountainous areas and rural women by conducting research on the available socio-economic and demographic data, which is currently insufficient. For this purpose, we conducted field research to gather socio-demographic and economic data related to gender structure in the Middle Taurus Mountainous Villages of Turkey.

\section{MATERIALS AND METHODS}

The main material for this study consists of data collected by means of questionnaires and faceto-face interviews in 146 households of 10 mountain villages in the Aladağ, Tufanbeyli, Kozan, Karaisalı, Saimbeyli, and Feke administrative districts of Adana. The authors implemented the questionnaires and conducted the research beginning in mid-2018 and completed it by the end of 2018 .

In mountainous areas, location was the main criterion for village selection in this study. Mountain villages were defined as villages where cultivable land is at 600 meters and above (ERKAN et al, 2001). The average altitude in the middle Taurus Mountains, which are located in the north, north-west, and north-east of Adana, is 3000 meters. Villages were randomly selected from every administrative district. Because of the homogeneity of selected administrative districts and villages, sampling rates were taken according to a fixed sampling rate, which varied between $10 \%$ and $50 \%$. This sampling rate was formed according to village population. The formula for the fixed sampling rate is $\mathrm{n} / \mathrm{N}=\%$, where $\mathrm{N}$ is main mass; $\mathrm{n}$ is number of households interviewed, and percent (\%) is the sampling rate used in the research (ARIKAN, 1995). Administrative Districts, villages, and the number of interviewees per household are listed in table 1.

Questionnaire forms were given to women and men living in the same household as a couple. In other words, data was collected from the household head and his wife to determine the differences according to gender using "simple probability sampling methods." In this way, 279 people (146 women and 133 men) were interviewed. The main reason for the lower number of males is death. To evaluate the collected data from the research areas, observations were made and a computer was used for proportional distribution, cross-tabulation, etc. Besides the questionnaire, a form was prepared to collect general information about each village: General Knowledge Form of Village. This form was completed together with the head (the muhtar) or the vice head of each village. Muhtar is defined as an elected person who is the official head of the village. Table 2 displays the socio-demographic and economic indicators from this portion of the study.

The collected data were analyzed using SPSS software. Frequency and percentage of the analyzed data were obtained. In addition, cross tables were formed between gender and education, selection of partner, and migration tendency of the respondents. Chi-Square independence test was used to determine the correlation between two categorical variables in the cross tables. Chi-square test was also used to evaluate the existence of independence. For the purposes of the test, a two-sided table (contingency table) was formed by arranging the observation results obtained from a sample group with a volume of " $n$ " based on the two qualitative variables used. The " $R$ " rows of the contingency table were allocated to the categories of one variable, while the "C" columns were allocated to the other variable's categories $(R \times C)$. The "observed frequencies" were entered in the cells located at the intersection points of rows and columns. In the chi-square independence test, the hypotheses are defined as follows (SERPER, 2017): $\mathrm{H} 0$ : There is no correlation between the variables. 
Table 1 - Administrative districts, villages and number of interviewed household.

\begin{tabular}{|c|c|c|c|c|c|c|c|}
\hline \multirow{2}{*}{$\begin{array}{l}\text { Administrative } \\
\text { districts }\end{array}$} & \multirow[t]{2}{*}{$\begin{array}{l}\text { Population } \\
(2018)^{*}\end{array}$} & \multirow[t]{2}{*}{$\begin{array}{l}\text { Household } \\
\text { number }^{* *}\end{array}$} & \multirow[t]{2}{*}{$\begin{array}{c}\text { Sampling rate } \\
(\%)\end{array}$} & \multirow[t]{2}{*}{$\begin{array}{l}\text { Number of household to be } \\
\text { interviewed }\end{array}$} & \multicolumn{3}{|c|}{$\begin{array}{l}\text { Number of interviewed } \\
\text { household }\end{array}$} \\
\hline & & & & & Women & Men & Total \\
\hline \multicolumn{8}{|l|}{------------. } \\
\hline Kökez & 1037 & 197.9 & 10 & 20 & 20 & 19 & 39 \\
\hline Ceritler & 974 & 185.9 & 10 & 19 & 19 & 16 & 35 \\
\hline \multicolumn{8}{|c|}{ 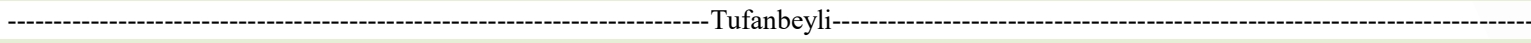 } \\
\hline Ayvat & 176 & 14.5 & 50 & 7 & 10 & 9 & 19 \\
\hline Çakırlar & 284 & 54.2 & 20 & 10 & 12 & 11 & 23 \\
\hline \multicolumn{8}{|c|}{ 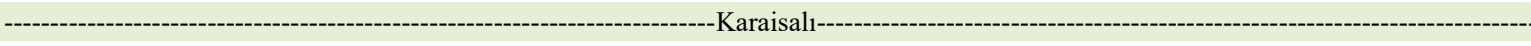 } \\
\hline Çevlik & 315 & 60.1 & 20 & 12 & 13 & 11 & 24 \\
\hline Gildirli & 170 & 32.4 & 20 & 6 & 9 & 8 & 17 \\
\hline \multicolumn{8}{|c|}{ - } \\
\hline Kızlarsekisi & 270 & 51.5 & 20 & 10 & 10 & 10 & 20 \\
\hline Yanalerik & 141 & 26.9 & 50 & 6 & 10 & 10 & 20 \\
\hline \multicolumn{8}{|c|}{ 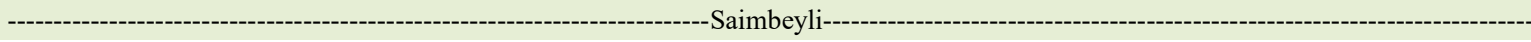 } \\
\hline Cumhurlu & 191 & 36.5 & 20 & 8 & 11 & 10 & 21 \\
\hline Eyüplü & 168 & 32.1 & 20 & 6 & 10 & 10 & 20 \\
\hline \multicolumn{8}{|c|}{ 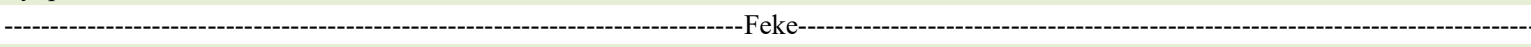 } \\
\hline Süphandere & 444 & 84.7 & 10 & 9 & 11 & 9 & 20 \\
\hline Güzpınarı & 479 & 91.4 & 10 & 9 & 11 & 10 & 21 \\
\hline Toplam & 4.649 & 871.1 & -- & 122 & 146 & 133 & 279 \\
\hline
\end{tabular}

*Resource: ANONYMOUS, 2018.

${ }^{* *}$ This number was found by dividing the population of villages by the average rural family size (5.24 person; ÇKA, 2011) of Adana.

$\mathrm{H} 1$ : There is correlation between the variables.

In the chi-square test performed to determine the correlation between gender and education, first marriage age, selection of partner, and migration tendency of the respondents, the test results were evaluated based on the Pearson chi-square significance level, since the proportion of cells with an expected value of $<5$ in the total number of cells was under $20 \%$ in the cross table (two-sided table).
In the study, the significance level for accepting or rejecting the $\mathrm{H} 0$ hypothesis was 0.05 .

The significance of the difference between the mean values of the two independent samples is generally tested with the Two Independent Samples T-Test. However, if data do not show normal distribution, the Mann-Whitney U test is used (ÖZDAMAR, 2013). In this study, the goal was to test whether the difference between the averages of the first marriage ages according

Table 2 - Socio-demographic and economic indicators.

\begin{tabular}{|c|c|c|}
\hline Main Indicators & Sub-division & Questioned indicators \\
\hline \multirow{2}{*}{ 1.Social } & General information about villages & $\begin{array}{l}\text { Basic infrastructure facilities like transportation, health services, etc. and } \\
\text { problems of villages }\end{array}$ \\
\hline & Education & Education status, average year spent on education, informal education \\
\hline \multirow{3}{*}{ 2.Demographic } & Birth & Gender, Birth place, Age structure \\
\hline & Marriage & $\begin{array}{l}\text { Marital status, First marriage age, Marriage decision, Child number, Family } \\
\text { type, Family size, Consanguineous marriage situation }\end{array}$ \\
\hline & Migration & Tendency to migrate to the cities \\
\hline 3.Economic & Occupation & $\begin{array}{c}\text { Occupation type, Definition of occupational status, Working hours, Number } \\
\text { of small ruminants, Land size. }\end{array}$ \\
\hline
\end{tabular}

Ciência Rural, v.49, n.12, 2019. 
to gender was statistically significant using the Two Independent Samples T-Test. However, since the data did not show normal distribution, the Mann-Whitney U test was used as a non-parametric test instead of the Two Independent Samples T-Test.

\section{RESULTS}

\section{Social Indicators}

General information about the villages and education Health services, formal and informal education, extension and other activities, and transportation facilities were weak and did not look promising for the future. In some villages, health services, houses, and schools exist but without personnel, or vice versa. There are no problems with electricity and drinking water, but irrigation water is insufficient. The main problems for the villages are explained as unemployment, high birth rate, insufficiency of irrigation water, lack of health and transportation services, and high tendency of young people to migrate to the city.

One of the most obvious features of Turkey's population is the high number of women among the total number of illiterate people. In Turkey, the number of illiterate women is five times higher than men among those aged 25 and above (TURKSTAT, 2018a). However, a better situation was observed in the research area. The research area revealed the number of illiterate women as 2.01 times higher than the number of men. The number of men is higher than the number of women in all levels except illiteracy, since there are no women at the high school level. There is a negative relationship between gender and the respondents' education level. The test result was evaluated based on the Pearson chi-square significance level and H0 was rejected since $.000<0.05$. We reported a negative correlation between education level and gender (Table 3 ).

Average number of years spent in education is very low for both sexes: 1.83 years for women and 3.61 years for men. Meanwhile, the average number of education years is 2.68 , leaving women far below the average.

Neither capacity building courses with technical content for agriculture nor courses for women's empowerment exist. In some villages, sewing courses were organized for women, but they were scheduled irregularly and overall insufficient. Meanwhile, women do not prefer to enroll in these courses because they are seen as proper only for young girls. Seventy-five percent of the women indicated that they prefer informal educational programs about small ruminants that discuss milking, feeding, and veterinary concerns. Many researchers focused on determinants of women's participation emphasize the importance of education, including BASLEVENT \& ONARAN, 2003, GÜNDÜZ-HOŞGÖR \& SMITS, 2008, and TAYMAZ, 2010

\section{Demographic indicators}

Birth, marriage, and migration

The gender ratio seen in the research area is higher for women due to death of men, especially

Table 3 - Education status by gender.

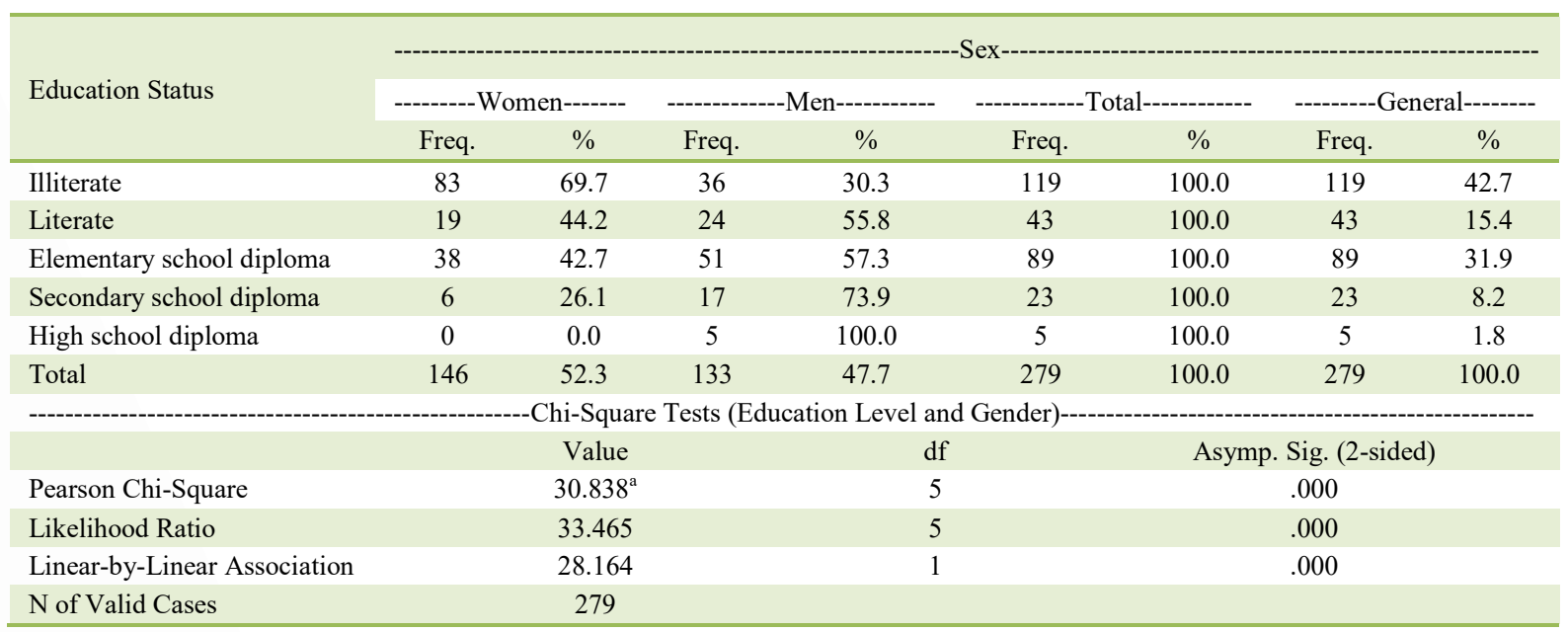

a. 2 cells $(20.0 \%)$ have expected count less than 5 . The minimum expected count is 2.38 . 
from old age. The sex ratio was reported to be $47.7 \%$ for men and $52.3 \%$ for women. All of the women and their husbands were born in the village. The average age was found to be 48.33 years for the research area (45.97 for women and 50.92 for men).

The research area recorded 13 widowed women. Consanguineous marriage is not common $(27.4 \%)$, but it is important. Fifty-six point eight percent of respondents explained their marriages as non-consanguineous, while $15.8 \%$ of women are married to a distant relative. In rural Turkey, choice of marriage partner was noted as generally being made according to the parents' decision; the majority of children voluntarily obey or accept this rule and tradition (SOYSAL, 1998). This traditional partner selection is called the "görücü" method in Turkish, and it is still an important practice. We reported that $24.0 \%$ of women and men (as couples) had married based on the "görücü" method $(60.2 \%$ of these were arranged marriages without input from the couple), while the rest of the respondents $(15.8 \%)$ had mutually agreed to marry based on making their own decisions. The selection of partner was not found to differ based on gender.

In rural areas, women marry earlier than men. In Turkey in 1970 (SIS), the average age at first marriage was found to be 17 for women and 21 for men. But age at first marriage age has increased over time. Today, this number is 24 for women and 27.1 for men (TURKSTAT, 2017) in Turkey. In the research area, the average age at first marriage was found to be 19.01 for women and 22.17 for men, compared to the general average of 20.52. Generally, age at first marriage varies across the 16-19, 20-22, and 23-25 age groups for both sexes. Test results were evaluated based on the Mann-Whitney U test significance level; H0 was rejected because $.000<0.05$. A statistically significant difference was found between average age at first marriage for women and average age at first marriage for men (Table 4).

Average number of children per woman in the research area was found to be 4.30 . None of the children were born in the hospital; all were born in the village like their parents, with midwife-led deliveries or simply help from older women in the community. In 1992, average household size in Turkey was 4.8 (SPO, 1993), and it is 3.4 today (TURKSTAT, 2018b). Average household size in the research area was reported to be 5.01, which is higher than the value measured in Turkey. In the research area, the most common family type was nuclear family $(83.6 \%)$, consisting of mother, father, and unmarried children, while the remaining families $(16.5 \%)$ live in
Table 4 - Test of difference of average first marriage ages based on gender.

\begin{tabular}{lc}
\hline & First marriage age \\
\hline Mann-Whitney U & 5741.500 \\
Wilcoxon W & 16472.500 \\
Z & -5.918 \\
Asymp. Sig. (2-tailed) & .000 \\
\hline
\end{tabular}

a.Grouping Variable: Gender of family members.

an extended family type. The nuclear family rate in Turkey is $66.1 \%$ (TURKSTAT, 2018b).

Fifty-nine point one percent of the people interviewed in the study did not indicate a desire to migrate to the city, while $28.0 \%$ stated that they were planning to migrate, and $12.9 \%$ did not know. However, the tendency to migrate to the city showed a significant difference in terms of gender. According to our findings, the tendency to migrate is higher in women and lower in men. Test results were evaluated based on the Pearson chi-square significance level, and $\mathrm{H} 0$ was rejected because $0.006<0.05$. A negative correlation was found between migration tendency and respondent gender (Table 5).

\section{Economic indicators}

In the research area, the main income resource is small ruminant rearing and crop patterns generally consisting of wheat, barley, and subsistence vegetable production. The average number of small ruminants per family was found to be 33.4 in the research area. Families generally have a very small amount of land for agricultural use; the approximate land size per family is 2.3 ha. In a study conducted in eastern Taurus villages, the average number of goats was found to be 32.9 head per family (DAVRAN, et al., 2018). The main occupation for men and women in the research area is farming. However, 76.7\% of interviewed women defined their occupation as housewife. In fact, they are not aware of their own farmer status, even when all of the families have small ruminant activity. Although, these women reported that they participate in all labor-intensive activities related to their small ruminants, livestock, and crop production, they still did not define themselves as farmers. This situation describes a typical woman's insight. Only $23.3 \%$ of women defined their job as farmer. But the majority defined the men's jobs as farmer $(89.04 \%)$, even though the women participate in all of the agricultural activities together with 
Table 5 - Migration tendency by gender.

\begin{tabular}{|c|c|c|c|c|c|c|c|c|}
\hline \multirow{3}{*}{ Tendency } & \multirow{2}{*}{\multicolumn{2}{|c|}{---------Women-------- }} & \multirow{2}{*}{\multicolumn{2}{|c|}{------------Men---------- }} & & & & \\
\hline & & & & & \multicolumn{2}{|c|}{-----------Total----------- } & \multicolumn{2}{|c|}{----------General----------- } \\
\hline & Freq. & $\%$ & Freq. & $\%$ & Freq. & $\%$ & Freq. & $\%$ \\
\hline Yes & 52 & 66.7 & 26 & 33.3 & 78 & 100.0 & 78 & 28.0 \\
\hline No & 74 & 44.8 & 91 & 55.2 & 165 & 100.0 & 165 & 59.1 \\
\hline Undecided & 20 & 55.6 & 16 & 44.4 & 36 & 100.0 & 36 & 12.9 \\
\hline Total & 146 & 52.3 & 133 & 47.7 & 279 & 100.0 & 279 & 100.0 \\
\hline \multicolumn{9}{|c|}{ 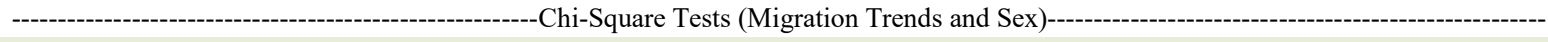 } \\
\hline & \multicolumn{3}{|c|}{ Value } & \multicolumn{3}{|c|}{ df } & \multicolumn{2}{|c|}{ Asymp. Sig. (2-sided) } \\
\hline Pearson Chi-Square & \multicolumn{3}{|c|}{$10.279^{\mathrm{a}}$} & \multicolumn{3}{|c|}{2} & \multicolumn{2}{|c|}{.006} \\
\hline Likelihood Ratio & \multicolumn{3}{|c|}{10.429} & \multicolumn{3}{|c|}{2} & \multicolumn{2}{|c|}{.005} \\
\hline Linear-by-Linear Association & \multicolumn{3}{|c|}{3.726} & \multicolumn{3}{|c|}{1} & \multicolumn{2}{|c|}{.054} \\
\hline $\mathrm{N}$ of Valid Cases & \multicolumn{3}{|c|}{279} & & & & & \\
\hline
\end{tabular}

a. 0 cells $(0,0 \%)$ have expected count less than 5 . The minimum expected count is 17,16 .

The file has been corrected by the author.

October 10, 2019.

the men. With the exception of two men, all of the men and women work in the village. Respondents reported that they believe that women can work in paid jobs before marrying, but that they should be feminine jobs like nursing, civil servant, etc. Women work 12.6 hours a day on average (except during crop production activities and seasonal agricultural working) considering their productive, reproductive, and community roles. Conversely, this number is only 4.5 hours per day for men.

\section{DISCUSSION AND CONCLUSION}

Obtaining socio-demographic and economic indicators for countries, especially in rural areas, is very important for gender studies' success as well as rural development efforts. This type of information can reveal a general picture of a rural area's gender structure; it can help guide the implementation of plans and programs for the public and private sectors with a focus on rural women and development. Indeed, based on BERTOLINI et al. (2008) findings, 59\% of the population live in rural areas in 27 EU countries; he also explained that demographics are among the key determinants of an area's economic growth, and they represent the basic information about the characteristics of the area's poor people. The OECD (2012) emphasized the importance of sustainable development needs in adopting a long-term approach that considers economic, social, and environmental issues at the same time, and where global and country level data is useful for policy-making. To reach this goal, socioeconomic and demographic indicator data should be collected regularly, especially in rural areas, to support and provide direction to development programs.

Important differences were reported between the indicators for men and women in the research area, except for in the selection of spouses, and this difference is to women's disadvantage. That is, this situation exists because of the patriarchal structure and gender inequality. Based on this, we concluded that women are given secondary status in all indicators which were investigated in terms of gender. These findings are similar to earlier studies on Turkey (like DİLDAR, 2015, KARAOĞLAN and ÖKTEN, 2012 etc.) and other countries (WEGREN et al., 2017, FERDOUS \& MALLICK, 2019, LOISON, 2019.). According to the Global Gender Gap Report (WORLD ECONOMIC FORUM, 2018), nearly 200 countries were considered, and the Global Gender Gap score stands at $68 \%$. This means that, on average, there is still a $32 \%$ gap to close between men and women. The Middle East and North Africa also have the worst values in the world at $60 \%$ and Turkey is located in this group.

These data reveal that women's secondary position in society is global. This situation is one of the main challenges for women's empowerment studies as well as for rural development efforts. In the research area, women are not aware of their productive roles as farmers even when they report 
themselves as participating in all of the agricultural work. Their working hours are approximately three times higher than men; yet women define the men as the farmers and themselves as the housewives. The research area has similar working hours with the rest of the world. Many women in the developing world work an average of 12-16 hours per day in agricultural activities (SINN et al., 1999).

Owing to their low education status, women do not have access to agricultural publications, qualified jobs; they also typically do not have the cultural sufficiency to socialize their children and do not have home economics and management education. There are no informal learning activities available in the research area, which are very important for empowerment of women at home and in society, especially as related to agriculture, home economics, financial literacy, management, etc. Although, men also have low education status in general, they receive education priority even if they do not ask for it. In terms of education, inequality exists between women and men not only in the research area but also in the rest of the world. According to the Global Gender Gap Report (WORLD ECONOMIC FORUM, 2018), while average progress on gender parity in education is relatively more advanced than in other aspects (employment, health, and politics, etc.), there are still 44 countries where over $20 \%$ of women are illiterate. This is not only a large literacy gap but also a large gender gap in many countries, and many women are still illiterate today. As stated by BADSIWAL (2015), education is the single most important factor for determining women's status in any society, because education liberates her from many disadvantageous conditions and promotes development. Women's status, particularly in rural communities is much more disadvantageous compared to men's in terms of quality of life indicators (BADSIWAL, 2015).

As a general observation, it can be said that age at first marriage is increasing for both women and men in the research area. A field study conducted in India revealed similar results (BATSIWAL, 2015). According to this study, contradictory to their hypothesis, the age at first marriage is increasing for girls; that is, $76 \%$ of respondents married at age 18 or above. According to the author, this is a remarkable finding. Nevertheless, age at first marriage should be higher because early marriages cause high birth rates and negative developments in maternal health. In other words, early marriage leads to longer pregnancy times for women during their fertile age, between 15 and 45. Indeed, studies conducted in India (MA, 2018), Bangladesh (WAHHAJ, 2018), and other developing countries (SANTHYA, 2011) also confirmed this information.

As a result, it can be said that women's secondary position (or gender inequality) in society is the main challenge facing rural and agricultural development efforts organized by the government, NGOs, and private sectors based on women's lack of cognitive competence. In fact, the main responsibility for this situation belongs to rural development programs, the patriarchal structure, and gender inequality. Women are generally ignored and humiliated by these three structures mutually. And the situation for rural women living in the Taurus Mountains of Turkey is similar to that of other rural women in the world. Indeed, "closing the gender gap" was identified by FAO (2004) as one of the most effective approaches to combating rural poverty and promoting agricultural and rural development.

To overcome these challenges, informal activities should be organized for women and men to discuss literacy, difficulties and effects of early marriage age, responsibility of having high numbers of children, home management, etc. These activities could be organized in coordination with non-governmental organizations, universities, and governments. Besides, the mentality of gender equity should be placed in policy applications and taught at related institutions. There is still a long way to go. Women are still ignored in government politics. In fact, in Turkey's National Rural Development Strategy (2014-2020), the definition of the target population was set as all households, with no priority given to disadvantaged groups such as women. And the report focused on agricultural enterprises, as usual (GTHB, 2015).

As a result of this research, the accuracy of gender-based observations in the research field has been proven and we are contributing concrete data to the literature. This is an important contribution since, according to SWOT analysis of Turkey's National Rural Development Strategy (GTHB, 2015), the insufficiency of rural data was explained as a weakness.

\section{ACKNOWLEDGEMENTS}

This work was not supported by any institution. We would like to thank the families who patiently answered us in the survey applications.

\section{DECLARATION OF CONFLICT OF INTERESTS}

The authors declare no conflict of interest. The founding sponsors had no role in the design of the study; in the 
collection, analyses, or interpretation of data; in the writing of the manuscript, and in the decision to publish the results.

\section{AUTHORS' CONTRIBUTIONS}

All authors contributed equally for the conception and writing of the manuscript. All authors critically revised the manuscript and approved of the final version.

\section{REFERENCES}

ARIKAN R. Araştırma Teknikleri ve Rapor Yazma. Ankara: Tutibay Yayınları, 1995. p.283.

ANONYMOUS. Global strategy for women's children's and adolescents' health 2016-2030. 2017. Available from: <https:// www.who.int/>. Accessed: Jul. 05, 2018.

ANONYMOUS. Türkiye Nüfusu İl İlçe Mahalle Köy Nüfusu. 2018 Available from: $<$ http://www.nufusune.com>. Accessed: Jul. 05, 2018.

BATANA YÉ. M. Multidimensional measurement of poverty among women in Sub-Saharan Africa. Social Indicators Research, v.112, n.2, p.337-362. 2013. Available from: <https:// link.springer.com/article/10.1007/s11205-013-0251-9>. Accessed: Jul. 05, 2018. doi: 10.1007/s11205-013-0251-9.

BADSIWAL R. Rural women and marriage. Sociology and Criminology-Open Access, 3:2. 2015. p.4. Available from: $<$ https://www.longdom.org/open-access/rural-women-andmarriage-2375-4435-1000129.pdf $>$. Accessed: Aug. 02, 2019. doi: $10.4172 / 2375-4435.1000129$

BENERIA L., BERIK, G., FLORO, M. Gender, development and globalization: economics as if all people mattered. 2nd Ed. New York: Routledge. p.348. 2015.

Bertolini, P., MOnTAnari, M., PERAGine, V. Poverty and social exclusion in rural areas: Executive summary. 2008. European Commission. p.29.

BOSERUP E. Population, the status of women, and rural development. Rural Development and Population: Institutions and Policy. v.15, p.45-60. 1989. Available from: <https://www. jstor.org/stable/i307528>. Accessed: Aug. 02, 2019.

BRYM R.; ANDERSEN, R. Democracy, women's rights, and public opinion in Tunisia. International Sociology. v.31, n.3, p.253-267. 2016. Available from: <https://www.sciencedirect. com/science/article/pii/S0305750X18304029>. Accessed: Aug. 02, 2019. doi: 10.1016/j.worlddev.2018.11.004.

CANTALINI S. Does education affect the timing or probability of family formation? An analysis of educational attainment and first union in Italy. Research in Social Stratification and Mobility. v.49, p.1-10. 2017. Available from: <https://www.sciencedirect. com/science/article/pii/S0276562416301019>. Accessed: Aug. 02, 2019. doi: 10.1016/j.rssm.2017.03.002.

ÇKA. Mevcut Durum Analizi, Çukurova Kalkınma Ajansı (Existing Situation Analysis, Cukurova Development Agency), Research Report 2011. Available from: $<$ http://www.cka.org.tr/>. Accessed: Aug. 15, 2018.

DHANARAJ S., MAHAMBARE V. Family structure, education and women's employment in rural India. World Development. v.115, p.17-29. 2019. Available from: <https://www.sciencedirect. com/science/article/pii/S0305750X18304029>. Accessed: Aug. 02, 2019. doi: 10.1016/j.worlddev.2018.11.004.

DAVRAN M.K., ÖZALP, B., SEÇER, A. Socioeconomic And Environmental Sustainability of Goat Breeding in Taurus Mountain Villages Located in The Eastern Mediterranean Region of Turkey: A Review After Ten Years. Fresenius Environmental Bulletin (FES), v.27, n.10, p.7112-7121. 2018.

DOSS C. Intrahousehold bargaining and resource allocation in developing countries. World Bank Research Observer. v.28, p.52-78. 2013.

ERKAN, O., et al. Sustainable development of small-scale farmers of the Taurus Mountains of Turkey. Aleppo-Syria: ICARDA. 2001.

FAO. National Sectoral Report on Women, Agriculture and Development (Iran, Benin, Cameroon, Honduras, Lebanon, Burkina Faso, Congo, EI Salvador, Mauritania and Egypt). 2004.

FAO. Rural women's economic empowerment (Delivers on FAO's Strategic Objective 3). 2014. Available from: <http:// www.fao.org/3/a-at890e.pdf>. Accessed: Aug. 02, 2019.

FERDOUS, J., MALLICK, D. Norms, practices, and gendered vulnerabilities in the lower Teesta basin, Bangladesh. Environmental Development. v.31, p.620-624. 2019. Available from: <https://doi.org/10.1016/j.envdev.2018.10.003>. Accessed: Aug. 02, 2019. doi: 10.1016/j.envdev.2018.10.003.

FOOD AND AGRICULTURE ORGANIZATION OF THE UNITED NATIONS. 2004 (Research Report). 2004. Available from: <http://www.fao.org/home/en/>. Accessed: Aug. 02, 2019.

GOODY, J. Futures of the family in rural Africa. Supplement: Rural Development and Population: Institutions and Policy. v.15, p.119-144. 1989.

ICIMOD. International Centre for Integrated Mountain Development Newsletter, n.29, Winter 1997, Nepal. 1997.

JENSON, R., THORNTON, R. Early female marriage in the developing world. Gender and Development. v.11, n.2, p.9-19. 2003. Available from: <https://www.tandfonline.com/doi/abs/10.1080/741954311>. Accessed: Aug. 02, 2019. doi: 10.1080/741954311.

KANTAR, M. Rural sociology and rural women. (Erkan, O., Beniwal, S.P.S., Ryan, J., Bounejmate, M., editors). Sustainable small scale farmers of the Taurus Mountains of Turkey. Aleppo-Syria:ICARDA, p.101. 2001.

KARAMAN, Y. Planlı dönemde kadın eğitimi politikamız. Ankara Üniversitesi Eğitim Bilimleri Fakültesi Dergisi. v.1, n.27, p.401-427. 1994.

KHURSHID, A. Domesticated gender (in) equality: Women's education \& gender relations among rural communities in Pakistan. International Journal of Educational Development, v.51, p.43-50. 2016. Available from: <https://www.sciencedirect. com/science/article/pii/S0738059316302024>. Accessed: Aug. 02, 2019. doi: 10.1016/j.ijedudev.2016.08.001.

KOCOURKOVA, J. Relationship between abortion and contraception: A comparative socio-demographic analysis of

Ciência Rural, v.49, n.12, 2019. 
Czech and Slovak populations. Women \& Health. v.56, n.8, p.885-905. 2016. Available from: <https://www.ncbi.nlm. nih.gov/pubmed/26789909>. Accessed: Aug. 02, 2019. doi: 10.1080/03630242.2016.1141829.

LOISON, S. A. Household livelihood diversification and gender: Panel evidence from rural Kenya. Journal of Rural Studies. v.69, p.156-172. 2019. Available from: <https://www.sciencedirect. com/science/article/pii/S074301671730205X > . Accessed: Aug. 02, 2019. doi: 10.1016/j.jrurstud.2019.03.001

MA, P., P. Maternal Age at Marriage and Adverse Pregnancy Outcomes: Findings from the India Human Development Survey, 2011-2012. Journal of Pediatric and Adolescent Gynecology v.31, n.6, p.620-624. 2018. Available from: <https://www.ncbi. nlm.nih.gov/pubmed/30107232>. Accessed: Aug. 02, 2019. doi: 10.1016/j.jpag.2018.08.004.

MAERTENS, A. Social norms and aspirations: age of marriage and education in rural India. World Development. v.47, p.1-15. 2013. Available from: <https://www.sciencedirect.com/science/ article/pii/S0305750X13000338>. Accessed: Aug. 02, 2019. doi: 10.1016/j.worlddev.2013.01.027.

MORRISON, A, RAJU, D., SINHA, N. Gender equality, poverty and economic growth. 2007. Policy Research Working Paper; No. 4349. World Bank, Washington, DC. Available from: <https:// openknowledge.worldbank.org/bitstream/handle/10986/7321/ wps4349.pdf?sequence $=1 \&$ isAllowed $=y>$. Accessed: Aug. 02, 2019.

OECD. Demographic Change and Local Development: Shrinkage, Regeneration and Social Dynamics. 2012. ISSN 2079-4797. p.26. Available from: <https://www.oecd.org/cfe/leed/ Demographic changes highlights.pdf $>$. Accessed: Aug. 02, 2019.

OGBUAGU, ST. Streamlining rural dimensions of genderpopulation concerns in UNFPA planning and programming activities. 1996. Available from: <https://www.unfpa.org/sites/ default/files/pub-pdf/gender-responsive.pdf $>$. Accessed: Aug. 02, 2019.

ÖZDAMAR, K. Paket programlar ile istatistiksel veri analizi. 9. Baskı. Cilt 1. Ankara: Nisan Kitabevi. n.584, p.2013.

SANTHYA, K.G. Early marriage and sexual and reproductive health vulnerabilities of young women: a synthesis of recent evidence from developing countries. 2011. Current Opinion in Obstetrics and Gynecology. v.23, p.334-339. 2011. Available from: <https://www. ncbi.nlm.nih.gov/pubmed/21836504>. Accessed: Aug. 02, 2019 doi: 10.1097/GCO.0b013e32834a93d2.

SERPER, Ö. Applied Statistics,. 8. Edition. Bursa: Ezgi Bookstore. p.1-701. 2017.

SINN, R., KETZIS, J., Chen, T. The role of women in the sheep and goat sector. Small Ruminant Research. v.34, p.259-269. 1999. Available from: <https://www.elseiver.com/locate/smallrumres $>$. Accessed: Aug. 02, 2019. doi: 10.1016/S0921-4488(99)00078-4.
SOYSAL, M. Rural Sociology. University of Cukurova, Faculty of Agriculture. n.211. p.160. Adana-Turkey. 1998.

SPO. A Research on Turkish Family Structure. Prime Ministry of Turkey State Planning Office (SPO), General Directorate of Social Planning. n. 2313, p.421, Ankara-Turkey. 1993

TOR, H., AĞLI, E. Women and education. Journal of Research in Education and Teaching. n.5, p.67-74. 2016. Available from: $<$ http://www.jret.org/FileUpload/ks281142/File/09.hacer_tor. pdf>. Accessed: Aug. 02, 2019.

TURKSTAT. Marriage and Divorce Statistics-2016. Turkish Statistical Institution Bulletin (Türkiye İstatistik Kurumu (TÜİK) Evlenme ve Boşanma İstatistikleri-2016 Haber Bülteni. 2017. Available from: $<$ http://tuik.gov.tr/Start.do $>$. Accessed: Aug. 02, 2019.

TURKSTAT. Women with Statistics-2017. Turkish Statistical Institution Bulletin (Türkiye İstatistik Kurumu (TÜİK) İstatistiklerle Kadın-2017 Haber Bülteni). 2018a. Available from: $<$ http://tuik.gov.tr/Start.do>. Accessed: Aug. 02, 2019.

TURKSTAT. Family Statistics-2017. Turkish Statistical Institution Bulletin. (Türkiye İstatistik Kurumu (TÜİK) İstatistiklerle Aile-2017 Haber Bülteni). 2018b. Available from: $<$ http://tuik.gov.tr/Start.do>. Accessed: Aug. 02, 2019.

UNESCO. Women and Girls' Education - Facts and Figures [electronic resource]. United Nations Educational, Scientific and Cultural Organization. 2014. Available from: $<$ https://en.unesco. org/>. Accessed: Aug. 02, 2019.

WAHHAJ, Z. An economic model of early marriage. Journal of Economic Behavior \& Organization. v.152, p.147-176. 2018. Available from: <https://www.sciencedirect.com/science/ article/pii/S0167268118301562>. Accessed: Aug. 02, 2019. doi: 10.1016/j.jebo.2018.06.001.

WORLD BANK - WB. Women in Development: Turkey. World Bank. p.205. 1993. Available from: <http://documents.worldbank. org/curated/en/308001468779359700/Turkey-Women-indevelopment>. Accessed: Aug. 02, 2019.

WEGREN, S. K., et al. Gender inequality in Russia's rural informal economy. Communist and Post-Communist Studies. v.50, v.2, p.87-98. 2017. Available from: <https://www.sciencedirect.com/ science/article/pii/S0967067X17300181>. Accessed: Aug. 02, 2019. doi: 10.1016/j.postcomstud.2017.05.007.

WORLD ECONOMIC FORUM. Global Gender Gap Report-2018. Switzerland. ISBN-13: 978-2-940631-00-1, p.355. Available from: <http://www3.weforum.org/docs/WEF GGGR 2018.pdf>. Accessed: Aug. 02, 2019

ZAINIDDINOV, H. Racial and ethnic differences in perceptions of discrimination among Muslim Americans. Ethnic and Racial Studies. v.39, n.15, p.2701-2721. 2016. Available from: <https:// www.tandfonline.com/doi/full/10.1080/01419870.2016.1164877. Accessed: Aug. 02, 2019. doi: 10.1080/01419870.2016.1164877. 